\title{
Craft Of Surkhanoakh From The History Of Development
}

\author{
G OPEN ACCESS \\ The American Journal \\ of Applied Sciences \\ JULY 2020 \\ Normatova Feruza Amonovna \\ Tashkent State Technical University \\ Termez Branch History Teacher,Uzbekistan \\ Page No.: 35-40 \\ Volume-II Issue-VII \\ PUBLISHED: 30 JULY 2020 \\ www.usajournalshub.com/inde \\ x.php/tajas \\ Copyright: Original content \\ from this work may be used \\ under the terms of the \\ Creative Commons Attribution \\ 4.0 licence.
}

\begin{abstract}
The article covers the history of handicrafts in the Surkhandarya oasis from ancient times to the early Middle Ages on the basis of scientific findings of archeological research conducted over many years. The main focus in the Surkhandarya oasis is on sewing, pottery, weaving, blacksmithing, glassmaking and shipbuilding in the Middle Ages. Also, Sopollitepa, Jarqo'ton, Budrachtepa, Kuchuktepa, Pishaktepa, Tallashkan, Jondavlattepa, Qiziltepa, Bandikhontepa, Gozimulla, Gozimulla, There are opinions about handicrafts found in Hayitobodtepa, Tumankurgan.
\end{abstract}

Key words: handicrafts, needles, pottery, pottery, keli, mill, textile machine, master potter, pottery wheel, metallurgy, weaponry, glassmaking, surmadons, knives, sickle, tesha, ketmon, candlestick, surmadon, eyebrow, mirror, xumdon. 


\section{Introduction}

The history of handicrafts in the Surkhandarya oasis dates back to ancient times. If we look at the history of handicrafts, archaeologists have found that a needle made of fish bone found in Mesolithic monuments (found in the Kayla monument, observed in Zarautsoy paintings) shows that Mesolithic people were engaged in sewing. This needle is reminiscent of modern needles in terms of shape and is the oldest needle. In the III-II millennia BC in Central Asia there was a second division of labor - the separation of agriculture from handicrafts. During this period, such crafts as metalworking, pottery, textiles became widespread. Since the end of the Neolithic period, pottery pots have been found, as well as material sources showing that soft stones were made of millstones. Although pottery originated in Central Asia during the Neolithic period, its rapid development is associated with the discovery of the pottery wheel in the Bronze Age. The introduction of the high-speed wheel in pottery allows for the production of a large number of high-quality, inexpensive, ceramic vessels of various shapes. Master potters with their own style and traditions emerge.

\section{The Main Findings And Results}

According to Academician A. Askarov, each mahalla had its own workshop with its own logo or logo. The discovery and exploration of Sopollitepa in the south of Uzbekistan was of great importance. Archaeologist AA Askarov studied this hill in detail. The findings from this monument belong to a culture whose first monument was named Sopollitepa. During the period of pottery culture, the production of pottery was highly developed. No pottery of any period can match the maturity, extreme delicacy, well-baked, light and resonant shape of the pottery, especially on the pottery wheel. At all stages of pottery culture, although pottery is similar to each other, if you look closely, you can feel the difference between them. In terms of its fineness and maturity of shape, the ceramics of the ceramic stage are superior to all other stage ceramics. By the Eneolithic period, pottery was much more developed. Pottery was no longer baked in an oven, but in jars. The quality of the pottery, baked in the fire, not in the fire, has changed dramatically in quality. The discovery of the pottery wheel in the Bronze Age (III-II millennia BC) led to the transformation of pottery, that is, to the creation of elegant and beautiful, rising to the level of a work of art. Pottery wheels and jugs created in the Bronze Age are still used in the pottery industry without any changes. The results of archeological research show that although the pottery of the Jarqoton stage was heavier and much rougher than the pottery of the pottery stage, it was observed that pottery neighborhoods appeared here. Later (at the end of the II millennium BC) there will also be settlements that specialize only in the production of pottery. Excavations in Jarqotan have uncovered a temple, a 
palace of rulers, defensive structures, handicrafts, the remains of monumental houses and high material culture typical of the first cities. Pieces of cloth from the monuments of this period, as well as from almost all settlements of this period, including the beginning of the weaving of silk and wool in the Eneolithic period In Sopollitepa, rugs and rugs used in textiles were found. It is safe to say that Uzbekistan was one of the first countries to produce silk. The discovery of textile looms in the same period, in turn, led to the development of textiles. One of the oldest written sources on the first types of handicrafts is also found in the Avesto. Farmers and herdsmen of the Avesto community knew and widely used iron, and in the Avesto they found words that meant special crafts

man,

potter,

weaver. Another type of handicraft in the Avesto is blacksmithing, although there is no definite information about the discovery of iron in general. A thief was found in a monument of the Early Iron Age located in the village of Gaz in Sherabad. It is made of soft, composite monolithic stone, $22 \mathrm{~cm}$ high, $20 \mathrm{~cm}$ wide and $12 \mathrm{~cm}$ deep inside. The thief (keli) was called "hovana" in Persian and was considered one of the most important items of fire in Zoroastrianism.

In the Videvdat section of the Avesto, EE Kuzmina found information about pottery jars. There is no information about the pottery wheel in the Avesto, and many researchers believe that the Avesto team did not know or use the pottery wheel. 36 monuments of ancient Bactrian culture have been identified in Surkhandarya region. Here Kuchuktepa, Pishaktepa, Tallashkan, Jondavlattepa, Qiziltepa, Bandikhontepa, Gozimulla, Hayitobodtepa and others. The Bactrians not only possessed advanced art, crafts and urban culture, but also under the influence of this culture Erkurgan in the Karshi oasis, ancient

Samarkand (Afrosiyob) and other cities were formed on the basis of the direct influence of Bactrian culture. During the reign of the Kushan kingdom, the Bactrian school of art was formed, which has its own unique works of art and style of construction. The pottery of the I and Kushan kingdoms has a very high quality workmanship and a diverse appearance. In the pottery of this period, silent cups with dark red paint, trays with red clay and gray content, jugs and jugs were common. During the last Kushan period (III-IV centuries AD), pottery was improved and carved and printed on the surface, such as various stars, "paw prints" of the

Buddha.

Part of the jugs are double-edged, and the bowls, the outside of the jugs, are decorated with shapes depicting the heads of animals such as monkeys or lions. In particular, the patterned earthenware found in the upper layer of Tumankurgan (Boysun) are unique specimens in the pottery of this period in Northern Bactria. On the outside of one of the hum jars there is a seal with a picture of a deer pierced by an arrow, while in the neck of the second jug there are two rows of prints of a deer ready to jump. In the early Middle Ages in the Surkhandarya oasis the glass-making type of handicrafts developed rapidly. 
In the early Middle Ages in the Surkhandarya oasis the glass-making type of handicrafts developed rapidly. Masters from Tokharistan made a variety of very delicate dishes from blue, blue bottles. Sources say that "Tokharistan masters learned some secrets of making porcelain bottles." It was during this period that handicrafts developed at a high level, and the types of this industry, such as ceramics, metallurgy, armaments, textiles, glassmaking, increased significantly. Even in 420, Bactrian glassmakers surprised the Chinese by making different colored bottles in the Chinese capital. In the early Middle Ages, blacksmithing also developed rapidly in the towns and villages of North-West Tokharistan. From the 5th century onwards, the deposits in Kohitang and Boysuntag began to be developed rapidly, and large fortresses and villages of miners were established there. The category of metal objects of this period includes a variety of surmadons, knives, work tools, including sickles, tesha, ketmons.

In the IX-XIII centuries, handicrafts developed rapidly in Termez and Chaghaniyan. The handicraft workshop was held in the cities as well as in the cities of Termez and Chaghaniyon, Garmalitepa near Dalvarzintepa was one of such pottery workshops in the countryside.

In Termez, the potters' mahalla covered several hectares. In this city, in addition to the neighborhood of potters, there was also a neighborhood of blacksmiths and glassmakers. Textiles were developed on the basis of cotton. The village of Darzangi in Chaghaniyon is considered the center of the textile industry. From here to the foreign market were produced yarn, yarn, cottonseed oil, various woven fabrics. The development of blacksmithing in the country was also greatly influenced by the rapid development of deposits in the Boysuntag and Kohitang mountains.

that is, from the 10th century onwards, large workshops and neighborhoods of mines appeared around Toda on the southern slope of Boysuntag, Khoja Kashkaron, Alami, Choyanli in Hamkon, and Kampirtepa (Konipur) in Kohitang. Blacksmiths made tools, household items, as well as antique candlesticks, antimony, brooches and mirrors. They took these items to the domestic and foreign markets and sold them. Such blacksmiths are the neighborhoods of Termez city near Amudarya, where they also sell their hand tools, household items, military weapons, horse equipment and others to the domestic and foreign markets. The masters of Termez and Chaghaniyan made iron products in the style of casting and hammering. Coppersmiths, on the other hand, made extensive use of carving and drawing techniques to decorate items. A treasure trove of metal vessels found during archeological excavations in the town of Budrach testifies to the rapid development of coppersmithing in the country. With a total weight of about 300 kilograms, which dates back to the XI century, this treasure consists of various utensils, including large pots, pots, candlesticks, jugs. During the ninth and twelfth centuries, local artisans skillfully made blue, air-colored glass cups, cans, bottles, flasks used by chemists, decanters, and 
cosmetics. In particular, the glass ornaments found in the palace of the Kings are distinguished by their unique luster. The jewelry depicts a wealthy rider with a bird of prey or a woman hunter holding a bird of prey in front of a horse. Another piece of jewelry has an Arabic inscription around the flying gazelle: "To Sultan Abul Muzaffar Bahrom, the sultan of the sultans." From the 9th century onwards, the making of glazed pottery was perfectly mastered in Termez and Chaghaniyon. Pottery of this period, especially bowls, bowls, plates, jugs, were painted in green, brown, and yellow glazes. One type of pottery is painted white and decorated with black and brown inscriptions in Kufic style. Some of the dishes are made in special molds. In the IX-XII centuries, the types of pottery were enriched again, decorated with colorful paints and covered with a glossy glaze over the patterns. Pottery similar to the pottery of Termez potters decorated with carved patterns is very rare, even in Samarkand, Merv, Bukhara, Binkent, which were the major centers of pottery at that time. After all, this is unique to the Termez pottery school. Termez potters were also famous in the Middle Ages for making mercury jugs. The mercury jugs they made were sold not only in the markets of Movarounnahr, but also in the markets of Khorezm, Khorasan, Iraq, and India. During this period, other areas of handicrafts developed in Termez. In this regard, it is possible to mention the shipbuilding, soap making industries. Large and small ships built in the city sailed between the cities on the banks of the Amudarya. According to sources, Termez is the largest port city on the Amudarya River. Termez shipbuilders also built large royal ships. The kings and sultans who came to Termez on these ships sailed on the river.

\section{CONCLUSION}

In conclusion, in the Surkhandarya oasis, handicrafts such as stone, wood, and bone were first used in the Mesolithic period, while sewing, pottery, and textiles were used in the Neolithic and Eneolithic periods. based on the above analysis, we can clearly see the existence of shipbuilding, which has played a major role in the development of trade. On the basis of these types of handicrafts, we can clearly see today that the next period developed "on the basis" of other types of handicrafts.

\section{REFERENCES:}

1. Askarov A. Drevnezemledelcheskaya kultura yuga Uzbekistana. - T.: Fan, 1977.

2. Askarov A.A., Shirinov T.Sh. Rannyaya gorodskaya kulturi i epoxi Sredney Azii., Samarkand, 1993.

3. "Avesto" Videvdat 8,84,85;

4. Annaev T., Shaydullaev Sh., Excerpts from the history of Surkhandarya., - T., A. Qodiriy National Heritage Publishing House, 1997. 
5. Annaev T. et al., Boysun Archaeological Monuments., -T., A. Qodiriy National Heritage Publishing House., 1999.

6. Annaev T. Rannesrednevekovye settlements severnogo Toxaristana. -T., «Fan», 1988. 7. Arshavskaya Z.A., Rtveladze E.V., Khakimov Z.A. Srednevekovye pamyatniki Surxandari.Izdatelstvo literatury i iskusstva Gafura Gulyama, 1982.

8. Isomiddinov M. History written in pottery.- T .: Science, 1993.11-p.

9. Masimov I. Ceramic production Yujnogo Turkmenistan epoxy bronze.

10. History of the Tajik people. $\mathrm{S}$ drevneyshix vremen do $\mathrm{V}$ veka $\mathrm{n} / \mathrm{e}$. Pod.red.B.G.Gafurova, B.A.Litvinskogo, T.I, M. 1963.

11. Kuzmina E.E., Otkuda prishli indoarii? -M., 1994.

12. Litvinskiy B.A., Solovev V.S. Medieval culture of Tokharistan. -M, Nauka, 1985.

13. Isaev A. Ergasheva S. Termez culture in IX-XII centuries, T. New Age Generation, 2001. p.35. 14. Pidaev Sh. Ancient Termez., T. Fan Publishing House, 2001. p.28.

15. Raxmonov U. Raskopki keramicheskix pechey Sapalli na poselenii Bustan 4. IMKU. Vyp. 15. - T., 1979

16. W.Geiger. Ostiranische Kultur im Altertum. Erlangen, 1882. pp. 47-148.

17. Sagdullaev A.S. Archaeological data in the study of the history of religious ceremonies reflected in the Avesto., The Avesto and its role in human development. TashkentUrgench, 2001, p.22.

18. Choriev Z., Shaydullaev Sh., Jubilee steps in the development of human thinking. TerDu News, 2006, №2. Page B.21. 